DOI: $10.2478 / \mathrm{v} 10025-010-0027-4$

JOURNAL OF WATER

AND LAND DEVELOPMENT

J. Water Land Dev. No. 13a, 2009: 177-185

\title{
The role and importance of forest watercourses and water reservoirs in designing landscape values of forests
}

\section{Emilia JANECZKO}

Warsaw University of Life Sciences, Department of Forest Utilization, Faculty of Forestry, ul. Nowoursynowska 163,02-787 Warsaw, Poland, e-mail: emilka.janeczko@wl.sggw.pl

\begin{abstract}
This paper presents some issues related to designing forest landscape located close to the areas of watercourses and water reservoirs. Surface waters, beside forests and diverse terrain relief, constitute the main element deciding about tourist and recreation attractiveness of every such area. Some surveys on the evaluation of forest recreational potential prove that the forest attractiveness is closely connected with the quantity and quality of water reservoirs and watercourses. Due do their functions (environmental, hydrological, economic and social), and the fact that over the past decades both their number and surface area have decreased, water areas require particular protection and concern. The aim of this paper is to highlight the necessity of defining the principles of designing forest landscape, with the consideration of the role of forest water areas in recreational and tourist development of forests.
\end{abstract}

Key words: aesthetics of landscape, landscape, landscape values, water reservoirs

\section{INTRODUCTION}

Watercourses and water reservoirs have always been an important element of the environment, used not only for economic and defence purposes, but also for recreation or solely aesthetic reasons. Water has also been an inspiration for various human artistic activities, for instance it appeared in a great number in paintings. The human willingness to be close to water is expressed through garden ponds and lakes, etc., set up in a way they exist in the natural environment. In the common belief, water is an element increasing the aesthetic attractiveness of space. Ponds and water courses also affect the visual attractiveness of forests. As shown by the results of surveys carried out by the Mazowiecki Landscape Park (JANECZKO, 2002), the greatest landscape attractiveness is presented by forest situated near water. Places perceived as being visually attractive are more keenly and more often visited by tourists because the aesthetics of the environment increases the comfort 
of recreation. The increasing tourist pressure on this type of areas imposes the necessity of their protection, not only in the natural but also in a visual sense. This is still more important since in the recent years many natural and artificial water reservoirs have for various reasons been eliminated MIODUSZEWSKI (2006). The liquidation contributed to significant, often negative, changes of landscape accompanied by the degradation of its natural values. The attractiveness of forest landscape is influenced not only by the number but primarily by the character of watercourses and water reservoirs. Artificial water reservoirs, created e.g. by open-cast mining activities or for fire-fighting purposes, as well as watercourses with regulated shorelines, may contribute to the decrease of aesthetic values. Untidy postexploitation areas, geometric shape of water reservoirs, built-over banks of watercourses, inappropriate location of recreation infrastructure, these are only some effects of human activities that cause peculiar dissonance in the landscape.

Due to the importance of aesthetics in human life, the uniqueness of forest watercourses and water reservoirs and to the fact that one of the purposes of sustainable forest management, according to the Law on Forests is care for landscape values of forests, it is essential to define the rules of protecting visual values of all forest areas, tree stands located in the neighbourhood of watercourses and water reservoirs regardless of their existing functions and protection status.

The aim of this paper is to find visual values and to define rules of protection of the forest areas located in the neighbourhood of watercourses and water reservoirs. These rules should mainly be implemented in areas intensively utilized for recreation, where landscape aesthetics is of key importance.

\section{LANDSCAPE VALUES OF FORESTS}

According to SKARŻYŃSKI (1992), landscape values mean a composition of space and objects causing aesthetic emotions in the observer. In the opinion of BOGDANOWSKI (1976), landscape constitutes an external physiocenosis of the Earth surface being a synthesis of natural and anthropogenic elements. According to KRZYMOWSKA-KOSTROWICKA (1997), every landscape forms a natural and cultural entity and is a synthesis of four types of perceived permanent space (comprising the terrain relief, buildings, the way of soil utilization etc.), semi-permanent space (changing throughout the year), non-permanent space (episodic), and the space (distances) of interpersonal and inter-production relations.

RICHLING and SOLON (1996) distinguish three components of landscape, such as: matrices, layers and corridors. The concept of layers and corridors is also known under the term a layer-corridor-matrix model, which was implemented to studies on landscape by ecologists (CIESZEWSKA, 2004, after Forman and Gordon, 1986). This concept is being developed in two directions: population - applicable in activities connected with environmental protection and landscape - used in spa- 
tial planning. More and more numerous publications and studies on landscape ecology show increasing importance of this theory.

The attempt of structural delimitation of forest landscape elements, according to the concept of layers and corridors, was presented by SMOLEŃSKI (2007). The author says that uniform tree-stands, with one or many species of trees, representing the same stage of development constitute the so-called landscape matrices, meaning vast areas consistent in terms of physiography. At the same time, nonforest enclaves, such as glades, small water reservoirs, clusters of old trees among young trees constitute landscape layers, meaning areas of surfaces smaller than matrices and visually distinguishable. The third element of landscape are connections between matrices and layers, called corridors, that may be of artificial (anthropogenic corridors), or natural (ecological corridors) character. In forest landscape these are streams, roads, log-rolling routes or lines of spatial division.

According to CIESZEWSKA (2004), an advantage of the layer and corridor model is its simple structure referring to a configuration of points, lines and surfaces. BELL (2001) refers to such depiction of landscape-forming elements. Small objects (e.g. a single tree or a beauty spot) are perceived in a landscape as points. Stretching a point in one direction forms a line (the edge of a forest). In an open (natural) landscape, which also includes forests, the most common are natural lines formed as a result of various natural processes. The third basic element of landscape are planes that may be perceived both as vertical units (e.g. rock or waterfalls), and horizontal (e.g. swamp pools or forest glades). According to BELL (2001), these three distinguished elements are accompanied by another one, volume, that may have a real, clearly definable dimension, or quite opposite - may only be perceptible, subjective (like the inside of a forest, formed by the horizontal plane of the bottom of the forest, and the tree trunks). Each of the aforementioned elements of landscape has attributes ascribed to it, features that determine their attractiveness. These attributes include for instance: location, orientation, size, shape, texture, colour, density, power of expression, and so on (BELL, 2001).

The physiognomy of forest landscape is formed primarily by vegetation, and this very property distinguishes it from other types of landscapes. In the opinion of WAŻYŃSKI (1997), the appearance of forest space is determined by the soil type, forest habitation, selection of species, age of tree-stands, clarity of the inside of the forest, and also physiographic conditions. Such a hypothesis is consistent with the results of studies on the landscape attractiveness of forests in the Mazowiecki Landscape Park (JANECZKO, 2002). The studies showed that the following features are responsible for visual perception of forest: the type of forest $-35 \%$ of provided answers, compactness (31\%), age of tree stands (19\%), and the character of soil (15\% of answers).

The study was part of doctoral dissertation made in the years 1999-2002. The social preferences were established with the questionnaire methods which involved 755 visitors in forests. 
Landscape values of forest constitute a tourist and recreation potential, and are subject to evaluation like other forest components. Their evaluation is a subject of studies carried out by specialists from various fields of science, landscape architects, geographers, and foresters. According to ŚLESZYŃSKI (1997), there are two types of evaluation of the landscape aesthetics the classic methods and the specialist ones. Classic methods, mainly the method of rank evaluation, entail the assignment of a specific point rank to selected components of landscape. The outcome of this type of method is a map of visual attractiveness of landscape that may apply to spatial units differing in size, and thus to planning scales. Examples of this type of evaluations may be found in ROŽKOV (1978) and in MARKEVIČ and ŠUŽMOV (1992). Criteria of evaluation of forest landscape elements considered in the above methods included for example the heterogeneity, vertical structure and age of a tree stand, sanitary condition, habitat moisture, colouring of tree stands, height and colouring of the undergrowth, "flourishness of vegetation", as well as species composition, the kind of tree crowns, and the size and growth stage of tree stands.

Nonetheless, in the evaluation of forest landscapes more widely applicable are specialist methods which include questionnaire surveys and surveys with the application of photographs and slides. Results of these studies show that from the aesthetic point of view the most desirable are mixed and deciduous forests, mature, with a broad selection of species (KELLOMÄKI and SAVOLAINEN, 1984; JENSEN, 1993), characterized by a moderate possibility of insight, of a park-like character, with a large number of spectacular and architectonically interesting single trees (JENSEN, 1993), with grass or herbaceous cover (O’LEARY et al., 1998).

\section{WATERCOURSES AND WATER RESERVOIRS AS ELEMENTS OF FOREST LANDSCAPE}

According to WOLSKI (2002), a watercourse is a general name for the mass of water flowing in a natural bed (natural water courses) or in artificial bed (artificial water courses) as a result of gravity. Natural watercourses include: trickles, streams, brooks, and small, medium-sized and large rivers. Artificial watercourses include ditches and canals. In forest areas watercourses often appear in the form of streams and small and medium-size rivers, as well as melioration ditches (draining or irrigating). Water reservoir is a hollow in the ground, filled with water having, unlike running water in rivers, a "standing" character (WOLSKI, 2002). Water reservoirs include: lakes, ponds, pits. In the forest landscape, we most often see small water reservoirs (ponds) with water surface of less than 1.0 ha (MIODUSZEWSKI, 2006). Such water reservoirs appear in the largest number in young glacial landscape, in the districts of Pomorze, Warmia and Mazury, and Wielkopolska. As in the case of watercourses, defining the type, volume, surface and a character of water reservoirs is very difficult. Many authors (e.g. JUSZCZAK (2003), MIODUSZE- 
WSKI (2006)) point out the need of registering surface waters in Polish forests. The presence of forest water reservoirs is often an argument for establishing nature reserves. Their landscape richness often predestines them as ecological land. Such areas are then excluded from economic utilization and recreation. Apart from natural water reservoirs, in the area of State Forests there are also the so-called excavations or pits, which are depressions in the ground created after open-cast mining activities (sand pits, gravel pits, turf pits, clay pits) usually filled with ground water.

Forest watercourses and water reservoirs contribute to the richness of landscape, authenticate the existence of view interiors, and break the monotony of forest. They ensure the change of view through the reflection of the environs in water surface, through which the space becomes optically larger. Besides, water areas are characterized by changing colours depending on weather, time of day and seasons of the year. In the formation of visual values of forests, greater role is attributed to water reservoirs than to water courses (JANECZKO, 2002). This is probably linked with the fact that water reservoirs, unlike watercourses, ensure relatively far insight into the landscape. The vastness of view is quoted in many papers (BELL, 2004; BOGDANOWSKI, 1976) as one of basic measures of landscape attractiveness of the area. Lowered land with small water reservoirs, turf and marshlands, constitute the so-called view (landscape) interiors.

Watercourses as linear elements of landscape (corridors) and forest water reservoirs (landscape layers) form internal ecotones i.e. zones where water and land meet, where the greatest abundance of life can be observed. The edge zone of a forest, in particular the water and forest border, is perceived as being visually most attractive (JANECZKO, 2002). According to SMOLEŃSKI (2007) it is the large diversity of ecotones that decides that watercourses as natural corridors and water reservoirs are visually one of the most attractive elements of forest landscape. This diversity also means contrasts in the natural landscape that, according to many authors, is an important criterion in choosing a place for recreation. It is difficult to point two elements in a landscape that would show more contrast and power of attracting tourists than forest and water. Therefore, the most preferred places for forest recreation are places located near watercourses and water reservoirs (JANECZKO, 2002).

\section{THE ROLE OF FOREST WATERCOURSES AND WATER RESERVOIRS IN RECREATIONAL FOREST MANAGEMENT}

Forest watercourses and water reservoirs constitute a recreational value of forests, they attract tourists. From various points, both formal, legislative, and protective, a significant number of them is used directly in recreation. They are not used for activities typically connected with aquatic environment such as: swimming, wa- 
ter sports, angling. Their presence promotes the arrangement of view and recreation points, and separation of cycling paths and sightseeing runs. Beauty spots in the neighbourhood of forest watercourses and water reservoirs often have the form of platforms and towers. Artificially organized view points are at the same time points of recreation. Their structure allows to enhance the viewing angle which is particularly important when the vegetation growing on the shore makes it difficult, or sometimes even impossible, to see the water surface. Another form of (natural) viewing points accompanying watercourses and water reservoirs are the view openings from the banks. Arranging a viewing point is connected with an appropriate layout of trees, which entails broadening of the existing gaps, removal, or trimming of extensively growing plants. Such treatments should also be carried out as regards communications router running along watercourses and water reservoirs. Landscape roads should be separated in a manner assuring the best possible diversity of landscape. This means the need for screening of certain fragments of a watercourse or a water reservoir for the benefit of wider openings in other places. According to WAŻYŃSKI (1997), view interiors accompanied by water should appear not more often than once every 100-200 m. The width of a strip at an observation point should be $10-20 \mathrm{~m}$, and at the view point $-50-100 \mathrm{~m}$.

Viewing points and routes are basic elements of the so-called active exposition of landscape. At the same time, passive exposition elements include view interiors, dominants, and so on. Exposition means exposing of particular sequences of landscape, the individual landscape interiors to human perception or drawing to them the attention of an observer - the tourist.

\section{POSSIBILITIES OF DESIGNING LANDSCAPE VALUES OF FORESTS IN THE NEIGHBOURHOOD OF WATERCOURSES AND WATER RESERVOIRS}

The matter of aesthetic designing of forest space is scarcely discussed in both the Instruction of Forest Arrangement and the Rules of Forest Cultivation, which constitute a general collection of instructions concerning the manner of forest management. The majority of postulates referring to the care of landscape values of forest apply to log-rolling areas, their relations to public roads and water areas. The instructions contained in the Rules of Forest Cultivation show that due to aesthetic purposes, log-rolling areas should not be set up near watercourses or water reservoirs. This clause in no way expresses the complexity of the process of forest designing in the context of its protection and improvement of its visual values. For various types of decisions in this matter, the necessary starting point should be the evaluation of landscape values.

Such evaluation, however, requires very thorough inventory of the area done in both micro- and macro-spatial scale, which would include certain features of wa- 
tercourses and water reservoirs affecting their visual perception. In a micro-scale it is essential to determine the character of bank zones of watercourses and water reservoirs (the height and slope of the banks, type of bottom, type of vegetation), water surface (location, size, shape, width of the bed), distribution and types of hydrotechnical appliances. In a broader concept, the inventory should provide information concerning the course/route, character and function of roads and forest paths located in a direct neighbourhood of water areas, distribution of view interiors (view openings) along the roads, the breadth of those openings (viewing angle), viewing distance, the character of closing of the view (type of vegetation, forms of terrain relief), and the appearance of landscape dominants (e.g. a group of plans distinguishable on the background of the uniform forest edge).

Collected information should be presented in a map of landscape resources, being at the same time a collection of instructions as regards forest arrangement and spatial planning. The landscape analysis, the results of studies on exposition, are an important factor deciding about the route of communication runs, distribution of landscape interiors, location of viewing points and main viewing axes.

Recreational access to the forest in the area of watercourses and water reservoirs means the necessity for elimination from its interior of any geometry as an element foreign to nature. Geometric shapes of water reservoirs reveal their artificial character and in the case of canals with flowing water, it is literally harmful since hardening of the bed with stones or concrete enhances the outflow of water and restricts its infiltration into the ground, cuts of bottom waters and causes death of these waters (BOGDANOWSKI, 1997). Too technical approach to regulation of water banks always gives unfavourable visual effects, which can be avoided by means of applying natural methods. Moreover, in close proximity of watercourses and water reservoirs accessible for recreation purposes, cutting, felling or other wood harvesting activities should not be carried out as they apparently interfere with the appearance of forest space. For arranging beauty spots, places should be chosen around which the vegetation is characterized by poor or extensive development and growth rate. When implementing recreational infrastructure, one has to remember that it should be attractive and visually harmonised with the surrounding. The infrastructure, in particular various types of view towers and platforms, should not close viewing axes, or constitute landscape dominants by themselves.

Protection of visual values, preservation of views stretching from viewing points, openings from landscape paths and roads, requires the establishment of zones of visual protection around the area in question. The directions of protection of panoramas and view openings (interiors) should refer to removing the risk of situating anthropogenic elements on viewing axes, including first of all the socalled small architecture. Protection of active exposition zones should primarily refer to, for example, a ban on afforestation of gaps that enable looking into the landscape. 


\section{SUMMARY}

Forest watercourses and water reservoirs play an important role in the designing of landscape values of forests, increase the aesthetics of forest space, contribute to the richness of landscape, and potentially are the best places for recreation. Their presence imposes the necessity for appropriate designing of the neighbouring tree stands to protect visual values of terrain. For this purpose, it is necessary to determine landscape resources of the forest, taking into consideration both distribution and character of elements of active and passive exposition of landscape. It is more so important that there is a programme of small retention implemented on a large scale in Polish forests. Basic elements of this program include construction and reconstruction of small water reservoirs and damming up of water in the beds of watercourses. Its execution will certainly limit negative processes resulting from previous land draining but also create a new type of landscape.

\section{REFERENCES}

1. BeLl S., 2001. Elements of visual design in the landscape. London, New York, Spon Press: 224.

2. BogDANOWSKI J., 1976. Kompozycja i planowanie w architekturze krajobrazu. Wrocław, PAN.

3. Cieszewska A., 2004. Płaty i korytarze - dyskusja pojęć. W: Płaty i korytarze jako elementy struktury krajobrazu - podstawy teoretyczne. Ed. A. Ciszewska. Probl. Ekol. Krajobr., 14: 13-18.

4. JANECZKO E., 2002. Środowiskowe i społeczne uwarunkowania funkcji rekreacyjnej lasów Mazowieckiego Parku Krajobrazowego (MPK). Sękocin, IBL PhD-Thesis.

5. JENSEN F.S., 1993. Landscape managers' and politicians' perception of the forest and landscape preferences of the population. For. Landsc. Res., 1: 79-93.

6. JUSZCZAK R., 2003. Inwentaryzacja przyrodnicza małych zbiorników wodnych na obszarach leśnych i zadrzewień powierzchniowych zlewni Rowu Wysokoć. W: Kształtowanie i ochrona środowiska leśnego. Ed. A.T. Miler. Poznań, Wydaw. AR Pozn.: 51-64.

7. KellomäKi S., Savolainen R., 1984. The scenic value of forest landscape as assessed in the field and the laboratory. Landsc. Planning, 11, 2: 97-107.

8. KRZYMOWSKA-KoSTROWICKA A., 1997. Geoekologia turystyki i wypoczynku. PWN, Warszawa.

9. MARKEWIČ I.A., ŠUŽMOV A.A., 1992. Metodika estetičeskoj ocenki elementarnych krajobrazov pri dviženii po maršrutam. Lesnoj Žurnal, 1.

10. MiodusZewSKI W., 2006. Małe zbiorniki wodne. Falenty, Wydaw. IMUZ: 127.

11. O'Leary T.N., McCormack A.G., Clinch J.P., 1998: Tourists' perceptions of forestry in the Irish landscape - an initial study. For. Landsc. Res., 1: 473-490.

12. Richling A., Solon J., 1996. Ekologia krajobrazu. Warszawa, PWN: 319.

13. RožKov L.N., 1978. Metodika estetičeskoj ocenki pejzažej. Les. Choz., 9: 23-26.

14. Schroeder H., W., DANIEL T.C., 1981. Progress in predicting the perceived scenic beauty of forest landscapes. Forest Sci., 27 (1): 71-80.

15. SKARŻYŃSKI Z., 1992. Ocena walorów estetycznych krajobrazu okolic Piecek na Pojezierzu Mazurskim. W: Metody oceny środowiska przyrodniczego. Warszawa-Płock-Murzynowo, GEA: 41-54.

16. ŚLESZYŃSKI P., 1997. Z badań nad fizjonomią środowiska przyrodniczego. Pr. St. Geogr. UW, 21, Warszawa, Wydaw. WGiSR UW.

17. SMOLEŃSKI M., 2007. Turystyczna percepcja krajobrazów leśnych. W: Sylwan 151, 3: 59-65.

18. URLiCH R.S., 1986. Human responsem to vegetation and landscapes. W: Landscape Urban Planning, 13: $29-44$. 
19. WAŻYŃSKI B., 1997. Urządzanie i zagospodarowanie lasu dla potrzeb turystyki i rekreacji. Poznań, AR: 216.

20. WOLSKI P., 2002. Przyrodnicze podstawy kształtowania krajobrazu. Słownik pojęć. Warszawa, Wydaw. SGGW: 243.

21. Zasady hodowli lasu, 2002. Bedoń, ORW LP: 159.

\section{STRESZCZENIE}

\section{Rola i znaczenie śródleśnych cieków i zbiorników wodnych w ksztaltowaniu walorów krajobrazowych lasu}

Słowa kluczowe: estetyka krajobrazu, krajobraz, walory krajobrazowe, zbiorniki wodne

W artykule przedstawiono zagadnienia dotyczące kształtowania walorów krajobrazowych w sąsiedztwie śródleśnych zbiorników wodnych i cieków. Wody powierzchniowe obok lasów oraz urozmaiconej rzeźby terenu stanowią podstawowy składnik decydujący o atrakcyjności turystyczno-wypoczynkowej każdego obszaru. Liczne badania nad oceną potencjału rekreacyjnego lasu dowodzą, że atrakcyjność terenów leśnych ma ścisły związek z występowaniem i jakością zarówno zbiorników, jak i cieków. Obszary wodne, ze względu na pełnione funkcje (przyrodnicze, hydrologiczne, gospodarcze, społeczne) oraz fakt, iż w ostatnich dziesięcioleciach istotnie zmniejszyła się zarówno ich liczba, jak i powierzchnia, wymagają szczególnej ochrony i dbałości. Celem artykułu jest zwrócenie uwagi na konieczność opracowania zasad krajobrazowego kształtowaniu lasu z uwzględnieniem roli i znaczenia śródleśnych obszarów wodnych w zagospodarowaniu turystyczno-rekreacyjnym.

Reviewers:

Dr. Ewa Kozłowska

Dr. Przemystaw Wolski 